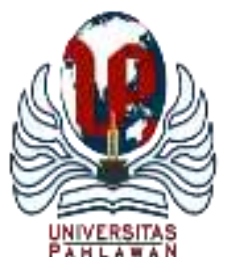

\title{
JURNALBASICEDU
}

Volume 6 Nomor 1 Tahun 2022 Halaman 646 - 655

Research \& Learningin Elementary Education

https://jbasic.org/index.php/basicedu

\section{Sosiolinguistik dalam Pembelajaran Teks Fabel dengan Pendekatan Komunikatif}

\author{
Huriyah Padhilah Anasti ${ }^{1 凶}$, Harris Effendi Thahar ${ }^{2}$, Afnita $^{3}$ \\ Program Studi Pendidikan Bahasa dan Sastra Indonesia, Universitas Negeri Padang, Indonesia ${ }^{1,2,3}$ \\ E-mail: $\underline{\text { 3030huri@gmail.com }}{ }^{1}$, harriseffendithahar@fbs.unp.ac.id ${ }^{2}, \underline{\text { afnita } @ f b s . u n p . a c . i d ~}^{3}$
}

\begin{abstract}
Abstrak
Tujuan dari penelitian ini adalah untuk melihat bagaimana kontribusi sosiolinguistik dalam pembelajaran teks fabel dengan menggunakan pendekatan komunikatif pada kelas VII SMP Negeri 2 Kerinci. Metode yang digunakan dalam penelitian ini yaitu deskriptif kualitatif. Sumber data dalam penelitian ini adalah proses pembelajaran teks fabel dengan pendekatan komunikatif. Dalam pengumpulan data teknik yang digunakan adalah observasi dan wawancara dengan guru dan siswa, hal ini mengingat keterbatasan akses dan ruang gerak pada masa pandemi sekarang ini. Adapun hasil yang diperoleh adalah pada pembelajaran teks fabel kelas VII SMP Negeri 2 Kerinci dapat diterapkan pendekatan komunikatif dengan baik. pembelajaran tersebut dimulai dari pembuka, inti, dan penutup yang kesemua langkah tersebut memperhatikan prinsip pendekatan komunikatif. Dalam pembelajaran dengan pendekatan komunikatif tersebut juga terdapat kontribusi sosiolinguistik di dalamnya, mulai dari proses penyusunan perangkat pembelajaran, pelaksanaan pembelajaran, hingga penggunaan bahasa dalam proses pembelajaran. Sehingga dapat disimpulkan bahwa dalam pembelajaran teks fabel terdapat kontribusi kajian sosiolinguistik dalam menerapkan pendekatan komunikatif.

Kata Kunci: Pembelajaran Teks Fabel, Pendekatan Komunikatif, Sosiolinguistik.
\end{abstract}

\begin{abstract}
The purpose of this research is to see how the contribution of sociolinguistics in learning fable text by using a communicative approach in class VII SMP Negeri 2 Kerinci. The method used in this research is descriptive qualitative. The data source in this research is the process of learning fable text with a communicative approach. In data collection, the technique used is observation and interviews with teachers and students, this is considering the limited access and space for movement during the current pandemic. The results obtained are that in learning fable texts for class VII SMP Negeri 2 Kerinci, a communicative approach can be applied properly. The learning starts from the opening, the core, and the closing, all of which take into account the principles of a communicative approach. In learning with this communicative approach, there is also a sociolinguistic contribution in it, starting from the process of preparing learning tools, implementing learning, to using language in the learning process. So it can be concluded that in learning fable text there is a contribution of sociolinguistic studies in applying a communicative approach.
\end{abstract}

Keywords: Fable Text Learning, Communicative Approach, Sociolinguistics.

Copyright (c) 2022 Huriyah Padhilah Anasti, Harris Effendi Thahar, Afnita

$\triangle$ Corresponding author :

Email:3030huri@gmail.com

DOI $\quad$ : https://doi.org/10.31004/basicedu.v6i1.1983

ISSN 2580-3735 (Media Cetak)

ISSN 2580-1147 (Media Online)

Jurnal Basicedu Vol 6 No 1 Tahun 2022

p-ISSN 2580-3735 e-ISSN 2580-1147 


\section{PENDAHULUAN}

Guru dan kompetensinya memiliki peranan yang penting dalam dunia pendidikan. Kompetensi psikologi guru dalam pembelajaran berperan dalam meningkatkan praktik mengajarnya (Suyitno, 2022). Selain itu kemampuan guru dalam melakukan adaptasi dan inovasi dalam pembelajaran terutama pada masa pandemi ini sangat diperlukan dalam kegiatan pembelajaran (Isrokatun et al., 2022). Inovasi guru dalam pembelajaran salah satunya adalah dengan bentuk penerapan budaya lokal dalam proses pembelajaran. Aswat et al., (2022) dalam penelitiannya menyatakan bahwa pembelajaran budaya lokal yang dimiliki oleh masyarakat setempat sangat penting untuk diterapkan. Hal ini mengingat bahwa dengan pembelajaran berbasis budaya lokal siswa dapat mengenal nilai-nilai karakter masyarakat setempat yang perlu ditanam. Dalam pembelajaran bahasa Indonesia di sekolah, penerapan budaya lokal dan bahasa salah satunya dapat dikatkan dengan implementasi kajian sosiolinguistik dalam pembelajaran.

Sosiolinguistik merupakan kajian yang di dalamnya mencakup bagaimana kondisi sosial mempengaruhi penggunaan bahasa. Bram \& Dickey (dalam Rokhman, 2013) menyatakan bahwa sosiolinguistik merupakan kajian yang khusus pada fungsi bahasa di tengah masyarakat. Sosiolinguistik berupaya menjelaskan tentang manusia dan kemampuannya dalam menggunakan aturan-aturan berbahasa secara tepat pada kondisi, keadaan, dan situasi-situasi tertentu yang bervariasi. Fishman (dalam Rokhman, 2013) menyatakan bahwa yang dipersoalkan dalam sosiolinguistik adalah siapa yang berbicara, kemudian apa bahasa yang digunakannya, kepada siapa, kapan, dan apa tujuan akhrinya. Sosiolinguistik sebagai suatu kajian tidak hanya sebatas melihat bagaimana bahasa di tengah masyarakat, namun juga dapat diterapkan dalam berbagai aspek. Penerapan praktis dari penelitian sosiolinguistik merupakan bagian dari kegunaan sosiolinguistik yang salah satunya dalam pengajaran bahasa kedua dengan pendekatan komunikatif.

Kajian sosiolinguistik pada pembelajaran melahirkan pendekatan komunikatif yang menikberatkan pada kebermaknaan bahasa dan pemaknaan bahwa bahasa itu bersumber pada situasi pada saat seseorang berbahasa. Sosiolinguistik pada pendekatan komunikatif menjelaskan terdapat kemungkinan perubahanperubahan variasi (ragam) bahasa dalam suatu pertemuan pembelajaran. Antara guru dan siswa bisa saja digunakan bahasa dalam bentuk ragam beku, resmi, santai ataupun akrab tergantung dari tuntutan pada setiap kegiatan di kelas. Dapat disimpulkan bahwa jika anggapan bahwa setiap ragam mewakili satu bahasa, maka kegiatan pengajaran di kelas akan selalu menampilkan corak komunikasi masyarakat multilingual (Muklis, 2011).

Kompetensi komunikatif lebih mengutamakan penggunaan bahasa pada fungsinya dalam komunikasi yang sesungguhnya dibandingkan pada penguasaan kaidah kebahasaan. Kaidah kebahasaan dalam pendekatan komunikasi hanya berfungsi sebagai monitor pada suatu bentuk ujaran (Krashen, dalam Rokhman, 2013)Terdapat dua pandangan terhadap pendekatan komunikatif dalam pembelajaran bahasa, yaitu pertama bahwa bahasa dipelajari dalam situasi yang semestinya memberikan makna kepada satuan bahasa yang dipelajari, dan kedua bahwa materi pembelajaran bahasa harus disajikan sesuai dengan situasi dan konteks pada saat berbahasa. Salah satu prinsip pembelajaran komunikatif yang dikemukakan oleh Canale dan Swain (Muradi, 2014) adalah kemampuan berbahasa sangat ditentukan oleh tingkat penguasaan kompetensi komunikatif yang terdiri atas kompetensi gramatikal, kompetensi sosiolinguistik, kompetensi kewacanaan, dan kompetensi strategis. Pada masa pandemik ini pada semua instansi pendidikan baik formal maupun nonformal, telah membuka celah baru dalam pelaksanaan sistem pembelajaran. Hal ini menyebabkan pembelajaran dengan pendekatan komunikatif harus diperhatikan (Sefriani, 2021).

Baik sosiolinguistik maupun pendekatan komunikatif dapat diterapkan dalam pembelajaran bahasa kedua di sekolah. Ada berbagai pembelajaran bahasa kedua, dimulai dari bahasa nasional berupa bahasa Indonesia, kemudian bahasa asing seperti bahasa Arab ataupun bahasa Inggris. Beberapa penelitian terdahulu telah melakukan penelitian pada penerapan kajian sosiolinguistik atau pendekatan komunikatif pada bahasa 
asing, seperti salah satunya bahasa arab. Pertama penelitian oleh Paramita (2017) dengan judul Implementasi Pendekatan Sosiolinguistik dalam Pembelajaran Bahasa Arab. Hasil yang diperoleh adalah bahwa penerapan sosiolinguistik dalam pembelajaran bahasatidak secara eksplisit dapat kita temukan. Kontribusi Sosiolinguistik dalam pembelajaran bahasa dalam aplikasi linguistik dibagi menjadi tiga tahap, yaitu tahap deskripsi linguistik, tahap silabus, dan tahap kegiatan pembelajaran bahasa. Penelitian kedua oleh Muradi (2014) dengan judul Pendekatan Komunikatif dalam Pembelajaran Bahasa Arab. Hasil yang diperoleh bahwa pembelajaran bahasa Arab dengan pendekatan komunikatif sebaiknya bersifat kreatif yang bisa membangkitkan minat belajar bahasa Arab dan motivasi berperan dalam aktivitas komunikatif, serta menciptakan situasi yang mendukung tujuan komunikasi yang sesuai dengan kebutuhan dan minat pebelajar terhadap bahasa Arab. Integrasi budaya ke dalam pembelajaran Bahasa Indonesia juga dapat membantu peserta didik meningkatkan kompetensi linguistik dan komunikatif siswa dalam komunikasi multikultural (Darojah, 2021).

Berdasarkan beberapa penelitian di atas, ternyata penelitian sosiolinguistik pada pendekatan komunikatif dalam pembelajaran bahasa Indonesia masih terbatas. Dalam pembelajaran bahasa Indonesia di sekolah terdapat berbagai bentuk materi pembelajaran terutama mengenai teks. Pembelajaran tersebut seharusnya juga dapat diterapkan pendekatan komunikatif dengan kajian sosiolinguistik. Salah satu teks yang dapat diterapkan adalah teks fabel. Teks fabel diajarkan di kelas VII SMP. Teks ini sangat dapat diajarkan dengan menggunakan pendekatan komunikatif mengingat bahwa teks fabel dapat dikaitkan dengan sosial masyarakat terutama jika menggunakan cerita fabel yang berkembang di masyarakat setempat. Dalam penerapan pendekatan komunikatif ini kajian sosiolinguistik juga dapat berkontribusi di dalamnya.

Danandjaya (dalam Aprima et al., 2018) menyatakan bahwa Fabel adalah dongeng yang tokohnya berupa binatang peliharaan dan binatang liar, seperti binatang menyusui, burung, binatang melata (reptilia), ikan, dan serangga. Jose, D'Anna, \& Krieg (dalam Dewi et al., 2018) menyatakan bahwa teks fabel merupakan cerita tentang binatang sebagai bentuk metafora dari tokoh manusia. Nurgiyantoro (dalam Ramadhani \& Syahrul, 2019) menyatakan bahwa cerita binatang (fabel) adalah salah satu bentuk cerita tradisional yang menampilkan binatang sebagai tokoh cerita. Binatang-binatang tersebut dapat berpikir dan berinteraksi layaknya komunitas manusia, juga dengan permasalahan hidup layaknya manusia. Mereka dapat berpikir, berlogika, berperasaan, berbicara, bersikap, bertingkah laku sebagaimana halnya manusia dengan bahasa manusia. Tujuan cerita ini adalah untuk memberikan pesan-pesan moral. Tokoh binatang tersebut hanya dijadikan sarana untuk memberikan pelajaran moral tersebut.

Urgensi sekarang ini bahwa belum ada penelitian yang mengkaji tentang bagaimana sosiolinguistik berperan dalam pembelajaran teks fabel dengan menggunakan pendekatan komunikatif. Beberapa penelitian memang telah mengkaji tentang penerapan pendekatan komunikatif pada beberapa jenis teks, seperti pertama penelitian oleh Lisnawati (2020) dengan judul Penerapan perangkat Pembelajaran Bahasa Indonesia Berbasis Pendekatan Komunikatif dalam Teks Prosedur Siswa Kelas VII SMP Methodist Pantai Labu. Adapun hasil dari penelitian tersebut adalah penerapan perangkat pembelajaran bahasa Indonesia berbasis pendekatan komunikatif dalam teks prosedur siswa kelas VII SMP Methodist Pantai Labu pada tahun pelajaran 2018/2019 adalah guru sudah menerapkan pendekatan komunikatif dengan tepat dalam pembelajaran bahasa Indonesia dengan penekanan pada aktivitas siswa. Dapat dilihat dari awal dan akhir pembelajaran siswa yang mengalami peningkatan dalam beberapa aspek.

Penelitian tentang kontribusi sosiolinguistik dalam pembelajaran bahasa Indonesia juga pernah dilakukan sebelumnya, yaitu oleh Mayasari \& Irwansyah (2020) dengan judul Peran Sosiolinguistik dalam Pembelajaran Bahasa Indonesia bagi Penutur Asing (BIPA). Adapun hasil yang diperoleh yaitu adanya peran sosiolinguistik dalam pembelajaran BIPA terdapat dalam kegiatan untuk menentukan bahasa pengantar, materi pembelajaran dan perencanaan pembelajaran (silabus). Pemilihan variasi bahasa yang menggunakan 
studi etnografi komunikasi dibutuhkan dalam pembelajaran dengan tujuan untuk terwujudnya komunikasi yang dapat dipahami antar partisipan dengan perbedaan budaya, bahasa dan adat istiadat.

Beberapa penelitian relevan telah dipaparkan dengan jelas di atas. Perbedaan penelitian ini dengan penelitian sebelumnya bahwa terdapat kebaharuan (novelty) yang sebelumnya belum pernah ada dalam penelitian terdahulu. Kebaharuan tersebut adalah bahwa penelitian ini mencoba mengkaji penerapan kajian sosiolinguistik secara teori maupun praktik dalam pembelajaran bahasa Indonesia di sekolah. Pembelajaran teks fabel merupakan objek penerapan kajian sosiolinguistik yang belum pernah dilakukan sebelumnya.

Kajian sosiolinguistik sangat berpotensi untuk diterapkan dalam pembelajaran teks fabel. Dalam pembelajaran teks fabel pembelajaran dan konteks sangat penting untuk dijadikan sebagai fokus utama pembelajaran. Hal ini sejalan dengan pendapat Stern (dalam Parera, 1986) yang menyatakan bahwa bahasa dan konteks merupakan dua dari empat konsep utama dalam pembelajaran di samping bahan ajar dan pembelajaran itu sendiri. Pada nyatanya potensi dan kesempatan ini belum dimaksimalkan oleh guru matapelajaran. Kajian sosiolinguistik masih sangat terbatas diimplementasikan dalam pembelajaran secara praktik langsung. Minimnya perhatian pada kajian antara pengajaran bahasa nampaknya tidak sejalan dengan pendapat Sagita (2019) bahwa pengajaran bahasa merupakan bidang yang penting untuk dikaji dan dibahas dalam perkembangan ilmu pengetahuan dan pengajaran. Oleh karena itu, peneliti ingin meneliti mengenai sosiolinguistik dalam pembelajaran teks fabel dengan pendekatan komunikatif kelas VII SMP. Adapun SMP yang dipilih adalah SMP Negeri 2 Kerinci. Sehingga, tujuan dari penelitian ini adalah untuk melihat bagaimana kontribusi sosiolinguistik dalam pembelajaran teks fabel dengan menggunakan pendekatan komunikatif pada kelas VII SMP Negeri 2 Kerinci.

\section{METODE PENELITIAN}

Metode yang digunakan dalam penelitian ini yaitu deskriptif kualitatif. Penelitian kualitataif menurut Moleong (2010) merupakan penelitian yang bertujuan untuk menyajikan dunia sosial dan perspektifnya dari segi konsep, perilaku, persepsi, dan persoalan tentang manusia yang diteliti. Dikatakan deskriptif sebab hasil penelitian ini akan disampaikan dalam bentuk kalimat atau kata-kata dengan tujuan untuk mendeskripsikan fenomena yang terjadi secara alami. Bagian yang akan dideskripsikan dalam penelitian ini adalah pembelajaran teks fabel dengan pendekatan komunikatif serta kontribusi sosiolinguistik di dalamnya. Sumber data dalam penelitian ini adalah proses pembelajaran teks fabel dengan pendekatan komunikatif. Dalam pengumpulan data teknik yang digunakan adalah observasi langsung dan wawancara dengan guru dan siswa. Tahapan penelitian yang dilalui adalah peneliti merancang rancangan pembelajaran bersama guru untuk satu kali pertemuan materi teks fabel dengan menggunakan pendekatan komunikatif. Selanjutnya dalam pembelajaran tersebut peneliti meminta guru untuk secara kreatif dan inovatif menggunakan kajian sosiolinguistik di dalam proses pembelajaran. Setelah merancang perangkat pembelajaran, guru akan menerapkan pembelajaran teks fabel dengan pendekatan komunikaif, sedangkan peneliti melakukan observasi terhadap proses pembelajaran. Kehadiran peneliti dalam penelitian adalah secara langsung melihat secara lamgsung proses pembelajaran yang berlangsung. Selain observasi secara langsung, peneliti juga melakukan wawancara bersama guru dan siswa. Penelitian ini dilakukan di SMP Negeri 2 Kelas VII B. Teknik yang digunakan peneliti untuk melihat keabsahan data adalah menggunakan teknik triangulasi.

\section{HASIL DAN PEMBAHASAN}

HASIL

Pembelajaran teks fabel di kelas VII SMP terbagi menjadi beberapa KD. Adapun KD yang ingin dicapai dalam pembelajaran teks fabel yang menjadi objek penelitian adalah menceritakan kembali isi teks 
fabel yang telah dibaca atau didengar. Adapun pembelajaran teks fabel dengan pendekatan komunikatif adalah sebagai berikut.

\section{Penyusunan perangkat pembelajaran}

Perangkat pembelajaran harus dirancang terlebih dahulu sebelum proses pembelajaran berlangsung. Adapun perangkat pembelajaran yang disusun oleh guru adalah silabus dan RPP. Penyusunan perangkat pembelajaran ini mempertimbangkan kebutuhan peserta didik. Ada beberapa hal yang perlu diperhatikan dalam penyusunan silabus atau RPP pada pembelajaran teks fabel dengan pendekatan komunikatif.

Pertama, guru memperhatikan jam pelajaran pada setiap kali pertemuan. Jam pelajaran pada setiap pertemuan harus diperhatikan, begitu juga dengan jumlah pertemuan yang akan dilaksanakan untuk satu KD teks fabel. Hal ini akan berpengaruh pada pemilihan materi atau bahan ajar yang tepat, media pembelajaran yang sesuai, dan model atau metode pembelajaran yang digunakan. Kondisi jam pelajaran yang sudah ditentukan menjadikan guru harus mampu memanfaatkan waktu semaksimal mungkin dan memilih berbagai penunjang pembelajaran yang cocok untuk digunakan. Pada masa pandemi ini dengan waktu pembelajaran yang masih sangat terbatas setiap pertemuannya, guru tentunya tidak memilih penggunaan media pembelajaran yang akan menghabiskan waktu yang lama, atau penggunaan model pembelajaran yang memiliki langkah rumit dan panjang. Waktu singkat yang tersedia harus benar-benar disesuaikan oleh guru dengan bahan ajar, media, model dan metode pembelajaran yang akan digunakan.

Kedua, kebutuhan siswa. Selain memperhatikan jumlah jam pelajaran pada setiap pertemuan, guru juga memperhatikan dan mempertimbangkan kebutuhan siswa dalam memilih bajan ajar, media pembelajaran, metode ataupun model. Adapun yang dibutuhkan siswa dalam pembelajaran teks fabel ini adalah pembelajaran yang dapat menjadikan mereka aktif dan mampu berkomunikasi secara timbal balik baik antar guru maupun antar siswa sesuai dengan pendekatan yang digunakan yaitu pendekatan komunikatif. Siswa juga membutuhkan pembelajaran yang didalamnya mereka dapat sekaligus melakukan pembelajaran bahasa kedua, atau dalam proses pembelajaran teks fabel siswa juga dapat memperoleh bahasa kedua mereka.

Setelah guru memperhatikan jam pelajaran dan kebutuhan siswa, selanjutnya yang ketiga adalah guru memilih bahan ajar, media pembelajaran, dan model atau metode pembelajaran. Adapun bahan ajar dipilih oleh guru dalam pembelajaran menceritakan kembali isi teks fabel yang telah dibaca atau didengar adalah berupa teks fabel yang berasal dari cerita rakyat daerah Kerinci Pulau Tengah. Teks fabel yang berupa cerita rakyat Kerinci Pulau Tengah yang dipilih masih dalam bentuk bahasa daerah Kerinci dialek Pulau Tengah. Pemilihan teks fabel ini tentunya telah disesuaikan oleh guru dengan kondisi kelas, yaitu seluruh siswa berasal dari daerah Pulau Tengah sehingga tidak akan terjadi kesulitan dalam membaca dan memahami teks fabel yang disediakan. Di samping itu tentunya adalah alasan lain mengapa guru memilih teks fabel berupa cerita rakyat Kerinci Pulau Tengah yang masih berbahasa daerah, yaitu guru ingin dalam pembelajaran teks fabel ini siswa secara tidak langsung memperoleh bahasa kedua mereka yaitu bahasa Indonesia melalui kegiatan menerjemahkan cerita fabel bahasa daerah Kerinci dialek Pulau Tengah ke dalam bentuk bahasa Indonesia secara bersama-sama. Setelah diterjemahkan secara bersama-sama siswa diminta untuk kembali menceritakan isi cerita fabel tersebut ke dalam bahasa tulisan dengan menggunakan bahasa Indonesia. Kegiatan demikian secara tidak langsung siswa telah belajar bahasa kedua mereka yaitu bahasa Indonesia karena bahasa pertama mereka adalah bahasa daerah yaitu bahasa Kerinci dialek Pulau Tengah. Adapun cerita rakyat yang digunakan sebagai bahan ajar teks fabel adalah cerita "Tupo Sarahei Dinga Luuk Mujeuk". Cerita rakyat ini diambil dari buku "Kumpulan Sakunung dari Uluk Ngoh Kincai Jambi" yang ditulis oleh Drs. Thahar Ramli seorang pensiunan dosen sejarah di IKIP Padang yang sekarang sudah menjadi Universitas Negeri Padang.

Kemudian, guru menentukan media pembelajaran. Media pembelajaran yang digunakan berupa lembaran kertas yang memuat teks fabel cerita rakyat “Tupo Sarahei Dinga Luuk Mujeuk". Pemilihan media pembelajaran ini dikarenakan beberapa alasan. Pertama, media pembelajaran lembar kertas ini dipilih karena dalam penggunaannya tidak membutuhkan waktu yang lama. Guru cukup membagikan lembar kertas untuk 
kemudian dibacakan oleh siswa sehingga waktu yang terbatas tidak terlalu banyak terbuang. Kedua, bahwa di SMP Negeri 2 Kerinci penggunaan media proyektor masih terbatas. Sehingga tidak memungkinkan guru menayangkan teks fabel melalui media proyektor baik berbentuk video ataupun tulisan. Ketiga, media lembar kerja memberikan kesempatan yang luas bagi anak atau peserta didik untuk membaca berkali-kali atau berulang-ulang sesuai dengan bagian yang mereka inginkan. Sehingga tidak mengganggu peserta didik lain dan mengurangi kegiatan kontak fisik sesuai dengan protokol kesehatan pada masa pandemi covid-19.

Setelah menentukan bahan ajar dan media pembelajaran, guru menentukan model dan metode pembelajaran. Adapun model yang digunakan oleh guru adalah model pembelajaran CIRC (Cooperative Integrated Reading and Composition). Pemilihan model pembelajaran ini didasarkan atas alasan bahwa model ini mengintegrasikan kegiatan membaca dan menulis dalam satu proses pembelajaran. Pada model ini siswa membaca teks yang telah diberikan oleh guru, kemudian berdasarkan teks tersebut siswa melakukan kegiatan menulis yang disesuaikan dengan tujuan pembelajaran. Pada pembelajaran teks fabel ini sangat cocok diterapkan model CIRC ini karena pembelajaran teks fabel ini bertujuan agar siswa mampu menulis kembali isi teks fabel yang dibaca atau didengar, jadi siswa akan melakukan kegiatan membaca terlebih dahulu yang kemudian dilanjutkan dengan kegiatan menulis. Selain itu, metode yang digunakan oleh guru adalah metode kooperatif, tanya jawab, dan demonstrasi.

\section{Proses pembelajaran}

Proses pembelajaran teks fabel dengan pendekatan komunikatif berlangsung sebagai berikut.

a. Pembukaan.

Ketika guru memasuki kelas masih terdapat siswa yang mondar mandir dan masih terdapat keributan pada deretan bangku belakang. Melihat hal tersebut hal pertama yang dilakukan oleh guru adalah menegur siswa-siswa tersebut. Bahasa yang digunakan oleh guru ketika menegur siswa-siswa tersebut adalah bahasa daerah Kerinci dialek Pulau Tengah. Dapat diketahui bahwa pada awalnya guru menggunakan ragam nonformal ketika berkomunikasi dengan siswa sebelum pembelajaran berlangsung.

Setelah kelas mampu dikondisikan oleh guru, kegiatan pertama memasuki proses pembelajaran adalah salam oleh siswa kepada guru dan guru menjawab salam. Setelah itu guru membuka kelas dengan menanyakan kabar siswa. Bahasa yang digunakan guru mulai berubah menjadi bahasa formal ketika pembelajaran berlangsung dengan menggunakan bahasa Indonesia. Selanjutnya, guru melakukan absensi terhadap siswa untuk mengetahui siswa yang tidak hadir pada pertemuan kali itu.

Setelah absensi, guru mulai bertanya kepada siswa satu persatu mengenai pembelajaran pada pertemuan sebelumnya. Guru mengajukan pertanyaan mengenai apa itu teks fabel. Setelah beberapa siswa menunjuk dan menjawab jawaban atas pertanyaan guru tersebut, kemudian guru menyampaikan tujuan pembelajaran pada pertemuan kali itu yaitu siswa dapat menceritakan kembali isi teks fabel yang dibaca atau didengar. b. Inti

Kegiatan inti dimulai dengan guru membagikan siswa dalam beberapa kelompok. Mengingat pada sekarang ini pembelajaran pada masa pandemi maka guru mengelompokkan siswa dengan jumlah satu kelompok berjumlah 4 orang. Sehingga siswa yang berada dalam satu kelompok dapat diberi jarak dan tidak duduk terlalu berdekatan dan berdempetan. Pengelompokan dilakukan dengan memperhatikan keheterogenan siswa. Hal ini tentunya disebabkan model pembelajaran CIRC yang digunakan menekankan pada pembentukan kelompok secara heterogen.

Setelah siswa dikelompokkan, selanjutnya setiap siswa diberikan lembar kertas yang memuat teks fabel "Tupo Sarahei Dinga Luuk Mujeuk". Guru memberikan instruksi setiap siswa memperhatikan teks fabel yang telah diberikan, kemudian menunjuk satu persatu siswa untuk bergiliran membacakan teks tersebut masing-masing satu paragrap. Setelah dibacakan satu paragrap, guru kemudian menunjuk siswa lain untuk menterjemahkannya ke dalam bahasa Indonesia. Jika siswa tersebut mengalami kesulitan, guru akan 
meminta bantuan siswa lain atau guru akan langsung membantu kesulitan siswa tersebut. Kegiatan ini dilakukan hingga seluruh paragrap teks fabel selesai dibaca dan diterjemahkan.

Selanjutnya, setelah semua siswa bersama-sama membaca dan menerjemahkan teks fabel tersebut, guru menunjuk satu persatu siswa untuk menjelaskan inti dari cerita fabel tersebut, atau menjelaskan siapa saja tokoh dalam cerita fabel itu. Pada kegiatan tanya jawab ini, ada beberapa siswa yang sulit mengungkapkan pendapatnya dengan menggunakan bahasa Indonesia. Guru kemudian meminta siswa tersebut untuk menjelaskan pendapatnya dalam bahasa daerah dan kemudian dibantu diterjemahkan oleh guru dalam bahasa Indonesia sampai anak tersebut bisa mengulang menyampaikan pendapatnya dalam bahasa Indonesia pula.

Setelah tanya jawab berlangsung, guru memberikan instruksi kepada siswa untuk menulis kembali isi dari teks fabel yang telah dibaca bersama-sama tersebut. Dalam mengerjakan latihan yang diberikan oleh guru ini, siswa diperkenankan untuk berdiskusi dengan teman satu kelompok, dengan catatan tidak menimbulkan keributan dan tetap menjaga jarak. Guru juga ikut serta dalam kegiatan ini. Guru tidak hanya lepas tangan dan membiarkan siswa bekerja sendiri, namun guru memantau setiap kelompok dan membantu setiap siswa yang mengalami kesulitan.

Setelah semua siswa selesai menuliskan kembali isi teks fabel tersebut, guru meminta beberapa siswa untuk maju membacakan hasil kerjanya. Kegiatan ini berlangsung hingga waktu 10 menit terakhir.

c. Penutup

Setelah memasuki 10 menit terakhir, guru meminta satu orang siswa untuk menyimpulkan pembelajaran pada hari ini. Dikarenakan tidak ada siswa yang bersedia, maka guru menunjuk salah satu siswa untuk maju. Siswa tersebut menyimpulkan pembelajaran pada pertemuan kali itu di depan kelas dan juga bersama-sama dibantu oleh seluruh siswa kelas. Setelah itu, guru menyampaikan materi yang akan dipelajari untuk pertemuan selanjutnya. Terakhir, pembelajaran diakhiri dengan salam.

\section{PEMBAHASAN}

Yuliati (2016) menyatakan bahwa pendekatan komunikatif memungkinkan pembelajar memiliki kesempatan yang memadai untuk mengembangkan kompetensi kebahasaan dan menunjukkannya dalam kegiatan berbahasa sesuai dengan situasi yang nyata baik yang bersifat produktif maupun reseptif, bukan situasi buatan. Sedangkan, Jazeri (2016) menyatakan bahwa dalam kelas dengan pendekatan komunikatif, aktivitas-aktivitas diorganisir untuk meningkatkan berbagai penggunaan bahasa secara fungsional dalam situasi sosial yang nyata. Situasi sosial tersebut juga meliputi salam, perkenalan, permintaan, perintah, pemberian informasi, dan ungkapan perasaan pribadi. Komunikasi yang otentik menuntut analisis terhadap berbagai materi dan tugas-tugas belajar agar tujuan pembelajaran dapat tercapai.

Berdasarkan hasil yang diperoleh, jika dilihat dari kontribusi sosiolinguistik dalam pendekatan komunikatif pada pembelajaran teks fabel maka diketahui bahwa penerapan pendekatan komunikatif sudah sesuai diterapkan oleh guru dalam pembelajaran teks fabel dan terdapat kontribusi sosiolinguistik. Hal ini tercermin mulai dari penyusunan perangkat pembelajaran. Pada penyusunan perangkat pembelajaran, guru memperhatikan kebutuhan-kebutuhan peserta didik dan disesuaikan dengan perangkat pembelajaran. Hal ini sejalan dalam Mayasari \& Irwansyah (2020) yang menyatakan bahwa aplikasi sosiolinguistik dapat terlihat dalam menentukan content dan sequent, yaitu pada tahap ini menentukan skill, bahan, strategi dengan memanfaatkan hasil analisis kebutuhan yang diperlukan peserta didik dalam dunia nyata. Kedua, kesesuaian tersebut juga tercermin pada kegiatan guru dalam pembelajaran yang menyajikan bahan ajar dan menggunakan bahasa yang sesuai dengan kondisi sosial peserta didik. Guru menyajikan bahan ajar berbasis cerita rakyat yang berkembang di daerah setempat. Sedangkan dalam penggunaan bahasa guru masih memaklumi adanya penggunaan bahasa pertama atau bahasa ibu berupa bahasa daerah meskipun guru berusaha memberikan pembelajaran bahasa kedua secara tidak langsung. Hal ini juga sejalan dalam Mayasari 
\& Irwansyah (2020) yang menyatakan bahwa aplikasi kedua sosiolinguistik dalam dilihat pada format dan penyajian, pada bagian ini guru memilih metode, strategi dan teknik dengan memperhatikan kondisi peserta didik, yakni bagaimana lingkungan peserta didik, bagaimana bahasa, budaya dan karakter peserta didik.

Selain itu, dua kegiatan tersebut juga sejalan dalam Asiah (2015) yang menyatakan bahwa silabus harus disusun searah dengan tujuan pembelajaran dan tujuantujuan yang dirumuskan dan materi-materi yang dipilih harus sesuai dengan kebutuhan siswa, dan guru telah melakukan hal yang demikian yaitu menyusunan perangkat pembelajaran termasuk silabus sesuai dengan kebutuhan siswa.

Jika ditinjau dari pendekatan komunikatifnya saja, guru telah menerapkan pendekatan komunikatif yang sesuai dengan prinsip yang dikemukakan oleh Littlewoo (dalam Muradi, 2014) sebagai berikut:

1) Bahasa yang disajikan adalah bahasa yang autentik, dipergunakan dalam realita kontekstual. Pembelajaran teks fabel menggunakan cerita rakyat yang berkembang pada masyarakat setempat dan menggunakan bahasa daerah kemudian diterjemahkan ke dalam bahasa Indonesia. Sehingga, penggunaan bahasa dalam pembelajaran ini merupakan bahasa yang autentik dan digunakan dalam realita kontekstual.

2) Bahasa tersebut dapat dipahami maksudnya oleh pembicara atau penulis sebagai bagian dari kompetensi komunikatif. Pemahaman bahasa dibentuk langsung melalui kegiatan menerjemahkan teks fabel bahasa daerah ke dalam bentuk bahasa Indonesia. Sehingga, maksud dari penggunaan setiap kalimat bahasa kedua yang digunakan dipahami maksudnya langsung oleh siswa.

3) Sasaran bahasa adalah wahana untuk komunikasi kelas, bukan sekadar objek belajar. Kegiatan penerjemahan yang melibatkan bahasa kedua dilakukan secara bersama-sama oleh siswa dalam satu kelas. Sehingga, hasil dari pembelajaran bahasa tersebut dapat digunakan sebagai wahana komunikasi kelas oleh siswa.

4) Satu fungsi dapat memiliki beberapa bentuk bahasa; fokus belajarnya bahasa yang digunakan secara realita; dan varian bentuk bahasa disajikan bersama-sama. Dalam pembelajaran guru tidak langsung menggunakan bahasa kedua seutuhnya. Guru masih memaklumi adanya penggunaan bahasa pertama oleh siswa dalam pembelajaran. Sehingga, dapat dikatakan bahwa dalam pembelajaran varian bentuk bahasa disajikan bersama-sama oleh guru.

5) Pembelajar mempelajari kalimat dalam suatu wacana, seperti kohesi dan koherensi. Dalam menulis kembali teks fabel tentunya siswa mempelajari kalimat dalam wacana teks fabel. Sehingga, jika siswa menulis suatu teks fabel secara utuh dalam bahasa kedua maka siswa telah mempelajari dan menggunakan kohesi dan keherensi dalam wacana mereka.

6) Pebelajar dapat menentukan keadaan belajar sesuai dengan realita komunikatif sehingga pembicara dapat langsung menerima umpan balik dari pendengar. Kegiatan tanya jawab, diskusi, dan kegiatan penerjemahan dilakukan bersama-sama antara guru dan seluruh siswa. Sehingga, siswa dapat secara langsung dapat menerima umpan balik dari lawak bicara atau pendengarnya.

7) Pebelajar diberi kesempatan untuk mengekspresikan ide dan opini mereka. Pada saat kegiatan menulis kembali teks fabel, siswa diberikan keleluasan dalam mengekspresikan ide yang mereka miliki.

8) Kekeliruan dapat diterima dan dinilai sebagai hal yang alami dalam pengembangan keterampilan komunikasi. Penggunaan bahasa pertama yang masih terjadi dalam pembelajaran teks fabel dimaklumi oleh guru dan kemudian diberikan secara langsung pembelajaran bahasa keduanya. Hal ini menandakan kekeliruan yang dialami siswa dapat diterima dan kemudian dikembangkan ke arah yang benar oleh guru.

9) Guru bertanggung jawab dalam menentukan situasi yang disukai untuk pengembangan komunikasi. Guru dalam pembelajaran teks fabel yang telah dilaksanakan melihat situasi peserta didik dalam melakukan komunikasi. Seperti kegiatan yang bagaimanakah yang harus dilakukan guru agar siswa dapat melakukan komunikasi dua arah, apakah dengan memberikan kesempatan untuk mereka mengajukan diri dalam kegiatan komunikasi atau dengan cara menunjuk. 
10) Interaksi komunikasi mendorong hubungan kerjasama antar pembelajar. Interaksi ini merupakan kesempatan bagi pebelajar untuk memahami atau negosiasi makna. Interaksi yang dilakukan pada saat menyelesaikan pekerjaan atau tugas yang diberikan oleh guru pada setiap individu dalam kelompok akan mendorong terbentuknya kerjasama antar siswa dalam komunikasi.

11) Konteks sosial dalam even komunikasi merupakan hal penting dalam pengungkapan makna yang diberikan. Komunikasi yang dilakukan oleh guru mencakup partisipasi seluruh siswa, sehingga ruang lingkup sosial yang diberikan lebih luas dan memberikan kesempatan yang luas dalam pengungkapan makna.

12) Belajar menggunakan bahasa yang tepat merupakan bagian penting dalam kompetensi komunikatif. Guru memberikan bantuan kepada siswa yang belum mampu menggunakan bahasa kedua secara benar, seperti siswa yang masih menggunakan bahasa daerah dalam pembelajaran.

13) Guru berlaku sebagai pembimbing dalam aktivitas komunikasi. Guru dalam pembelajaran teks fabel yang telah dilakukan membimbing siswa agar terbentuknya suatu aktivitas komunikasi, baik dalam bentuk kegiatan kelas, kelompok, ataupun individu.

14) Dalam komunikasi, pembicara dapat memilih tentang apa yang dikatakan dan bagaimana mengatakannnya. Dalam menulis kembali teks fabel, siswa diberikan keleluasan untuk bagaimana mereka menyampaikan ide mereka sendiri.

15) Para pebelajar mempelajari gramatika dan kosakata melalui fungsi, konteks situasional, dan peran pada teman bicara. Secara tidak langsung, kegiatan-kegiatan komunikasi yang secara langsung dilakukan oleh guru telah memberikan pembelajaran baik secara gramatika, kosa kata maupun kontekstual terhadap penggunaan bahasa kedua.

16) Para pembelajar diberikan ruang untuk mengembangkan strategi dalam memahami bahasa sebagaimana yang digunakan para penutur bahasa tersebut. Guru membebaskan siswa untuk memahami bahasa sesuai dengan strategi mereka masing-masing, sehingga pembelajaran bahasa kedua yang dilaksanakan benar-benar dapat diperoleh oleh siswa.

Penelitian ini juga masih terbatas dalam temua penelitian, yaitu penelitian ini belum mendapatkan bagaimanakah hasil belajar siswa dengan menerapkan pendekatan komunikatif dan kajian sosiolinguistik dalam pembelajaran teks fabel. Meskipun demikian, temuan dan hasil penelitian ini sangat bermakna bagi perkembangan keilmuan terutama dalam bidang pembelajaran bahasa dan sosiolinguistik. Hal ini dikarenakan bahwa hasil temuan yang diberikan oleh penelitian ini memberikan teori dan masukan baru bagi pembelajaran bahasa dalam melakukan pembelajaran yang baik dan tepat serta kreatif dan inovatif bagi siswa.

\section{KESIMPULAN}

Berdasarkan pemaparan dari hasil penelitian di atas, diketahui bahwa pada pembelajaran teks fabel kelas VII SMP Negeri 2 Kerinci dapat diterapkan pendekatan komunikatif dengan baik. pembelajaran tersebut dimulai dari pembuka, inti, dan penutup yang kesemua langkah tersebut memperhatikan prinsip pendekatan komunikatif. Dalam pembelajaran dengan pendekatan komunikatif tersebut juga terdapat kontribusi sosiolinguistik di dalamnya, mulai dari proses penyusunan perangkat pembelajaran, pelaksanaan pembelajaran, hingga penggunaan bahasa dalam proses pembelajaran. Sehingga dapat disimpulkan bahwa dalam pembelajaran teks fabel terdapat kontribusi kajian sosiolinguistik dalam menerapkan pendekatan komunikatif.

\section{DAFTAR PUSTAKA}

Aprima, R., Abdurahman, A., \& Arief, E. (2018). Pengaruh Model Discovery Learning Terhadap Keterampilan Menulis Teks Fabel Siswa Kelas Vii Smp Negeri 16 Padang. Jurnal Pendidikan Bahasa 
Dan Sastra Indonesia, 7(1), 215-221.

Asiah, A. (2015). Pendekatan Komunikatif Dalam Pembelajaran Bahasa Indonesia Untuk Meningkatkan Keterampilan Berbicara Siswa Di Kelas Iv Sd. Mimbar Sekolah Dasar, 2(1), 21-35.

Aswat, H., Fitriani, B., Onde, M. K. L. O., Sari, E. R., \& Yansen, W. D. (2022). Analisis Iklim Dan Budaya Sekolah Di Masa New Normal Terhadap Penguatan Pendidikan Karakter Berbasis Budaya Lokal Po-5 Sejak Dini. Jurnal Basicedu, 6(1), 287-297.

Darojah, R. (2021). Persepsi Guru Sekolah Dasar Terhadap Integrasi Budaya Pada Pembelajaran Bahasa Indonesia. Edukatif: Jurnal Ilmu Pendidikan, 3(6), 3748-3757.

Dewi, H. G., Suwignyo, H., \& Maryaeni, M. (2018). Bahan Ajar Menulis Teks Fabel Bermuatan Nilai Kehidupan. Jurnal Pendidikan: Teori, Penelitian, Dan Pengembangan, 3(8), 1032-1038.

Isrokatun, I., Yulianti, U., \& Nurfitriyana, Y. (2022). Analisis Profesionalisme Guru Dalam Pelaksanaan Pembelajaran Daring Di Masa Pandemi Covid-19. Jurnal Basicedu, 6(1), 454-462.

Jazeri, M. (2016). Model Perangkat Pembelajaran Keterampilan Berbicara Dengan Pendekatan Komunikatif Kontekstual Bagi Mahasiswa Asing. Litera, 15(2), 217-226.

Lisnawati. (2020). Penerapan Perangkat Pembelajaran Bahasa Indonesia Berbasis Pendekatan Komunikatif Dalam Teks Prosedur Siswa Kelas Vii Smp Methodist Pantai Labu. Edumaspul Jurnal Pendidikan, 4(1), 260-270.

Mayasari, D., \& Irwansyah, I. (2020). Peran Sosiolinguistik Dalam Pembelajaran Bahasa Indonesia Bagi Penutur Asing (Bipa). Jurnal Pendidikan Tambusai, 4(1), 189-199.

Moleong, L. J. (2010). Metode Penelitian Kualitatif. Bandung:Rosdakarya.

Muklis, M. (2011). Pengajaran Bahasa Dalam Perspektif Sosiolinguistik. Dinamika Ilmu: Jurnal Pendidikan, $11(1), 1-12$.

Muradi, A. (2014). Pendekatan Komunikatif Dalam Pembelajaran Bahasa Arab. Arabiyat: Jurnal Pendidikan Bahasa Arab Dan Kebahasaaraban, 1(1), 29-48.

Paramita, N. P. (2017). Implementasi Pendekatan Sosiolinguistik Dalam Pembelajaran Bahasa Arab. AlManar, 6(2), 163-191.

Parera, J. D. (1986). Linguistik Edukasional: Pendekatan Konsep Dan Teori Pengajaran Bahasa. Jakarta: Erlangga.

Ramadhani, P., \& Syahrul, R. (2019). Pengaruh Penggunaan Teknik Think Talk Write (Ttw) Terhadap Keterampilan Menulis Teks Fabel Siswa Kelas Vii Smp Negeri 31 Padang. Jurnal Pendidikan Bahasa Dan Sastra Indonesia, 8(2), 66-73.

Rokhman, F. (2013). Sosiolinguistik: Suatu Pendekatan Pembelajaran Bahasa Dalam Masyarakat Multikultural. Yogyakarta: Graha Ilmu.

Sagita, K. M. (2019). Pengembangan Sosiolinguistik Dalam Pengajaran Bahasa (Secara Teoritis Dan Penerapan) Bagi Mahasiswa Pendidikan Bahasa. Jurnal Sains Riset, 9(2), 49-57.

Sefriani. (2021). Efektivitas Pembelajaran Online Di Masa Pandemi Covid-19. Edukatif: Jurnal Ilmu Pendidikan, 3(6), 58-65.

Suyitno, S. (2022). Penerapan Kompetensi Psikologi Guru Dalam Peningkatan Motivasi Belajar Siswa. Jurnal Basicedu, 6(1), 58-65.

Yuliati, A. (2016). Penerapan Pendekatan Komunikatif Dalam Pembelajaran Bahasa Indonesia. Wahana Pedagogika, 2(1), 29-34. 